\title{
Förnyelse i språkutbildningen \\ - pedagogiska argument för en problembaserad undervisning
}

\section{Av Mathias Pålsson, doktorand i franska}

\author{
Länk till presentation av Mathias Pålsson
}

- Förnyelse i språkutbildningen

- Bakgrund

- Litteratur

- Disposition och begränsningar

- Vad är PBL?

- Termen PBL

- Bakomliggande pedagogisk idé

- Kort historisk tillbakablick

- PBL som förhållningsätt

- PBL som arbetsform

- De sju stegen

- Examination

- Vilka erfarenheter finns av PBL och språkundervisning?

- PBL i språkundervisningen på grundläggande nivåer

- Är PBL effektivare än traditionell undervisning?

- Några reflexioner

- Litteraturförteckning

Det finns flera goda skäl till att intressera sig för problembaserat lärande (PBL) i språkundervisningen.

För det första verkar denna undervisningsmetod inte i någon större omfattning ha fått genomslag inom den högre språkutbildningen. Åtminstone har sådan försöksverksamhet inte dokumenterats i skrift. Att döma av den litteraturgenomgång som jag gjort i samband med denna artikel är det i gymnasieskolan som experiment med denna nya undervisningsform huvudsakligen genomförts.[1] Av denna anledning kan det vara av värde dels att redovisa hur dessa experiment utfallit och vilka erfarenheter som dragits från gymnasieskolan, dels att med utgångspunkt i litteraturen försöka inventera och möjligen förutse hur ett problembaserat lärande skulle kunna gestalta sig på akademisk nivå.

För det andra, om denna undervisningsmetod ännu inte prövats i språkundervisningen är det rimligt att anta att närmare kännedom om de grundläggande pedagogiska principerna i PBL inte är allmänt förekommande. En ovillkorlig förutsättning för att PBL ska få något som helst gehör och kanske i förlängningen kunna prövas inom ramen för en delkurs är att undervisande lärare ges tillfälle att bilda sig en uppfattning om vad PBL är och hur PBL skiljer sig från traditionell undervisning. Som K. Kjellgren m.fl. (1993) påpekar måste man mycket noga inventera och analysera alla argument för och emot en förändrad utbildning. Det kan därför vara motiverat, tror jag, att presentera en - om än elementär och ofullständig - kort presentation till PBL. En av ambitionerna med denna artikel är just att den ska kunna läsas som en kort introduktion där argument från pedagogisk vetenskap får ta plats med redan vunna erfarenheter.

För det tredje verkar det finnas anledning att ifrågasätta den traditionella utbildningens effektivitet. När man talar med universitetslärare idag - inte bara inom humanistisk fakultet - så 
anser många att studenternas förkunskaper är otillräckliga och att detta är en tendens som blivit särskilt stadig under de senaste åren. Och om vissa studenters kunskaper är otillräckliga i terminsstarten, verkar många av dem sakna incitament att kompensera denna deficit efterhand, i alla fall om man ska gå efter det timantal som de själva uppger att de lägger ner på sina studier räknat per vecka.[2] Man kan naturligtvis invända för det första att lärare alltid har ansett studenternas förkunskaper vara otillräckliga och för det andra att studenter knappast någonsin lär ha läst så mycket som de borde. Om det faktiskt är på detta vis, finns det ännu större anledning, menar jag, att inte bara ompröva utan även att förändra de traditionella undervisnings- och examinationsformerna. Mycket av den pedagogiska forskning som gjorts under de senast tre decennierna har dessutom kunnat lägga fram argument som närmast talar emot det sätt på vilket akademisk undervisning traditionellt meddelas och examineras.

För det fjärde det är det som lärare såväl stimulerande som meriterande att ägna sig åt pedagogiskt utvecklingsarbete. Vid tjänstetillsättning så tyder mycket på att pedagogisk verksamhet kommer att bli allt viktigare.[3] Redan idag slås det fast i Högskoleförordningen (4 kap $5 \S \mathrm{HF}$ ) att "lika stor omsorg skall ägnas prövningen av den pedagogiska skickligheten som prövningen av den vetenskapliga skickligheten". Även om det hittills har ansetts svårt att evaluera pedagogisk skicklighet står det klart att det nu finns principer för bedömning utarbetade vid de flesta universitet och högskolor.[4] Det gäller även vid Växjö universitet, där det i utvecklingsplanen för 2000-2004 understryks att "Studenten ska ges möjligheter till en aktivare roll i såväl universitetets arbete i stort som i sin kunskapsinhämtning" samt att: "Universitetet ska öka sina insatser att stimulera till nya pedagogiska arbetsformer inom grundutbildning och medverka till att erfarenheter sprids."[5] PBL kan här vara ett alternativ att pröva.

\section{Bakgrund}

Avgörande för tillkomsten av denna artikel har varit de frågor som väcktes av Lars Owe Dahlgrens uppslagsrika föreläsning på UPC-kursen i högskolepedagogik 1999/2000 och som jag alltsedan dess finner anledning att återkomma till. Eftersom jag inte har stor erfarenhet av att undervisa,[6] inte vare sig på gymnasium eller på högskola, var min föreställning om pedagogikens möjligheter vid UPC-kursens början mycket begränsad. Man kan säga att jag sakförde den primitiva uppfattningen att lärare inte är något som man blir utan något som man redan från början är. Denna hållning har jag funnit anledning att radikalt ompröva, och läsaren kommer därför att emellanåt märka en viss candidesk optimism inför det problembaserade lärandets potential.

\section{Litteratur}

Den litteratur som använts kan delas in i anslutning till de frågor som behandlas i artikeln. Som allmän introduktion till lärande har jag haft stor nytta av Ulike perspektiv på lcering og leingsforskning (1996) av O. Dyste, Hur vi lär (1998) under redaktion av F. Marton, D. Hounsell och N. Entwistle samt Learning to teach in higher education (1992) av P. Ramsden. Dessa tre böcker har kompletterats dels av Frihet, ansvar, kompetens. Grundutbildningens villkor i högskolan (SOU 1992:1) och Nya villkor för lärandet i den högre utbildningen (SOU:2001:1), dels av Högskoleverkets skriftserie, i synnerhet några rapporter med inriktning på examination, nämligen Uppfattningar om examination - en intervjustudie (1997:3 S), Examination vid universitet och högskolor - ur studentens synvinkel (1997:10 S), Extern medverkan i examinationen. Nordiska och brittiska traditioner. Svenska försök (1997:11 S), En auktoritär prövning eller en prövning av auktoritet? Examination vid universitet och högskolor (1997:12 S) samt Råd och idéer för examinationen inom högskolan (1997:14 S). Vad beträffar PBL i allmänhet har jag främst använt Problembaserat lärande i praktiken - För gymnasieskolan (1999) av L. Alanko \& L. Isaksson, Problembaserat lärande - en introduktion för lärare och lärande (1999) av H. Egidius samt Problembaserad inlärning - erfarenheter från Hälsouniversitetet (1993) under redaktion av K. Kjellgren m.fl.

Störst betydelse med hänsyn till artikels målsättning och utformning har emellertid $P B L i$ 
språkundervisningen. Om problembaserat lärande i teori och praktik (1996) av G. Oliveira \& M. Berggren haft, kanske främst tack vare dess grundliga och verklighetsnära helhetssyn. Slutligen har jag på ett allmänt pedagogiskt plan låtit mig provoceras av I. Enkvists eldande Feltänkt. En kritisk granskning av idébakgrunden till svensk utbildningspolitik (2000) samt av B. Brodows, N.-E. Nilssons \& S.-O. Ullströms Retoriken kring grammatiken. Didaktiska perspektiv på skolgrammatik (2000).

\section{Disposition och begränsningar}

Artikeln innehåller tre avsnitt som i stort sett utvecklar de punkter som angavs i inledningen och som låter sig formuleras i frågeform:

- Vad är PBL?

- Vilka erfarenheter finns av PBL och språkundervisning?

- Är PBL effektivare än traditionell undervisning?

Till dessa tre frågor kunde jag ha lagt ytterligare en:

- Är PBL möjligt att införa i ämnet franska vid Växjö universitet?

Jag är medveten om att den sistnämnda frågan är tämligen självklar i sammanhanget och att man kunde förvänta sig att den behandlades i denna artikel. På ett sätt har den ett omedelbart svar, nämligen att det naturligtvis är fullt möjligt att använda PBL i ämnet franska vid Växjö universitet. Trots detta har jag valt att i denna artikel begränsa mig till att försöka förstå vad PBL är och vilka erfarenheter som finns av PBL och språkundervisning. Att arbeta med PBL leder bl. a. till en annorlunda och vidgad lärarroll samt ändrade behov i fråga om lokaler, bibliotek och organisation. Ett eventuellt införande av PBL har emellertid föga att vinna på snabbehandling, och jag har därför föredragit att inte här diskutera denna fråga utförligare; det är emellertid min avsikt att återkomma till den i ett annat sammanhang.

Artikelns första avsnitt inleds med en kort tillbakablick som genom att redovisa den bakomliggande pedagogiska idén försöker sätta in PBL ett större sammanhang. Denna tillbakablick lägger grunden för den skillnad som sedan görs mellan PBL som förhållningssätt och PBL som arbetsform. Det andra avsnittet presenterar i urval några de erfarenheter som gjorts dels av PBL i allmänhet, dels av PBL inom språkundervisningen. I artikelns tredje och sista avsnitt finns pedagogiska argument för ett problembaserat förhållningssätt i den högre språkutbildningen.

\section{Vad är PBL?}

\section{Termen PBL}

Termen PBL kommer från engelskans problem-based learning. När denna term skulle översättas till svenska valde man först benämningen problembaserad inlärning, PBI. Men ordet inlärning kom stegvis under 1990-talet att anses som mindre lämpligt, eftersom man hade börjat att betrakta lärande som något mer än bara passivt kunskapsmottagande. I lärandet ingår inte bara förvärvande av vetande utan också, som Egidius (1999:6) påpekar "reflexion, utveckling av studieförmåga, lärstrategier, träning i kritiskt tänkande och sätt att lära tillsammans med studiekamrater". När man idag översätter learning med lärande är det på goda grunder, eftersom det på ett tydligt sätt associerar till aktivt kunskapssökande.

Det kan vara på sin plats att här sätta in termen PBL ett större sammanhang. I stora drag brukar man idag tala om SCE (Student-centered Education) och DBE (Disciplin-based Education). DBE är synonymt med traditionell undervisning, medan SCE, under vilken PBL sorterar, är en samlingsbeteckning för en rad nyare undervisningsformer som t.ex. SBL (Situation-based learning), CBL (Case-based learning) och PBE (Project-based education). 


\section{Bakomliggande pedagogisk idé}

Ifall det har funnits delade meningar om terminologin inlärning/lärande, står det klart att det råder enighet i fråga om innehållet. En kort genomgång av den vanligast förekommande litteraturen om PBL bekräftar detta. K. Kjellgren m.fl. (1993:23-27) skriver att "PBI är inte bara en pedagogisk metod, utan innebär också ett förändrat sätt att se på lärandet, bl.a. är den studerandes intresse, aktivitet och ansvarstagande centralt [...] problembaserad inlärning är ett sätt att utforma utbildningar så att alla studerande får förutsättningar att göra på samma sätt när de lär sig som de mest framgångsrika ändå skulle ha gjort". Oliveria \& Berggren (1996:14) understryker att PBL står "för en viss kunskaps- och inlärningssyn [...] som samtidigt erbjuder en yttre arbetsform som gör det möjligt att omsätta den bakomliggande kunskaps- och inlärningssynen i praktisk verklighet". Egidius (1999:5) skriver om PBL att det är: "både en fråga om att söka kunskap och utveckla färdigheter självständigt och att basera förvärvet av kunskaper på aktuella och realistiska problem inom området." Alanko \& Isaksson (1999:26) slår fast att: "Grunden i problembaserat lärande, PBL, måste vara ett visst förhållningssätt till människan och kunskap [...] en tro på att människan är en social varelse som lär bäst tillsammans med andra, eller snarare lär mera och bättre tillsammans med andra."

Vad betyder då allt detta? Ja, PBL är med andra ord en fråga om att upptäcka och ta ansvar för sitt lärande. Det innebär att kunskap inte bestäms i kvantitet utan snarare i kvalitet, d.v.s. förmåga att tillämpa sin kunskap. Denna kunskapssyn medför, vilket kanske kan tyckas märkligt, att en kvantitativ ökning av kunskapen inte per se medför att lärande kommer till stånd. Verkligt lärande, påpekar Oliveira \& Berggren (1996:14), äger nämligen inte rum förrän den som lär förändrar sin egen omvärldsbild med hjälp av sina nyvunna kunskaper.

Den som läser ovanstående citat och försöker bilda sig en uppfattning om vad PBL är kan med visst fog tycka att han inte blivit mycket klokare. Detta kan förstås bero på många faktorer, men till tröst kan jag säga att detta är ganska naturligt, eftersom man normalt skiljer på PBL som förhållningssätt och PBL som arbetsform. Det som jag givit exempel på hittills är PBL som förhållningssätt och då i mycket allmänna termer. Nedan följer en redogörelse för vad som ligger bakom dessa begrepp, men först kan det vara motiverat att gå ungefär 30 år tillbaka i tiden och se vilka betingelser som syresatte den jordmån i vilken rötterna till dagens PBL kunde växa fram.

\section{Kort historisk tillbakablick}

Om man ska sätta in PBL i ett historiskt sammanhang låter det sig lämpligast göras mot bakgrund av de stora omvälvningar som hela det högre utbildningssystemet i västvärlden genomlevde under slutet av 1960-talet. Det missnöje som fanns hos studenterna mot hur den akademiska utbildningen var organiserad tog sig uttryck i handgripligheter, som samtidigt kompletterades med en rad krav. Studenterna krävde, som t.ex. Oliveira \& Berggren (1996:14) uppmärksammar, att den auktoritära undervisningen vid universiteten skulle reformeras, att traditionellt teoretiska utbildningar skulle öppnas mot verkligheten och att de studerande själva skulle få större inflytande över sitt lärande.

I kölvattnet av denna turbulens insåg några lärare i medicin vid McMaster-universitetet i Kanada, att utbildningen av läkare måste reformeras. 1980 gav en av dessa lärare, H.S. Barrows, i samarbete med en kollega, ut boken Problem-based learning. An Approach to Medical Education. Denna bok tas upp av Alanko \& Isaksson (1999:34), som skriver att den innehåller en beskrivning av en förändrad läkarutbildning med simulerade patienter där de studerande får träna sig genom att lösa olika fall som läkare möter i sitt dagliga arbete. Fallbeskrivningarna byggs på under problemlösningens gång och arbetssättet är noga genomtänkt enligt en viss problemlösningsstrategi. Läraren fungerar som en handledare, vars viktigaste uppgift är att göra lärandet studentcentrerat i stället för lärarcentrerat. Läraren håller diskussionerna vid liv genom att ställa frågor till de studerande i stället för att ge svaren. Nyfikenhet och upptäckarglädje blir drivkraften för de studerande. 
PBL visade sig vara så tilltalande att det under 1980-talet spreds till en rad universitet värden över. I Sverige var det Linköpings universitet som först anammade PBL genom att 1986 införa denna pedagogik på medicinska fakulteten.[7]

\section{PBL som förhållningsätt}

Jag nämnde tidigare att det är väsentligt att skilja mellan PBL som förhållningssätt och PBL som arbetsform. Varför är det väsentligt? När PBL presenterades var det som en ny pedagogik för hur man lägger upp och genomför utbildningar och kurser. Allteftersom PBL har tillämpats i olika miljöer har man kommit att se det som en arbetsform bland andra. Detta innebär att PBL ställs vid sidan av andra metoder som t.ex. föreläsning, seminarium och projektarbete. Om det är arbetsformen som avses ska man vara klar över att den har en jämförelsevis fast arbetsordning, den så kallade sjustegsmetoden. Denna kommer att presenteras i nästa avsnitt om PBL som arbetsform.

Som förhållningssätt kan PBL upplevas som mycket progressivt. Egidius (1999:14) erinrar om att: "några av pionjärerna gick ut med fältropet: No ex cathedra education (ingen katederundervisning, d.v.s. slut på allt föreläsande). Deras grundtanke var att lärarna ska ha en renodlat ny roll. De ska vara handledare, inte undervisare." Den enkla motiveringen till detta var att de studerande, i förläsningar och katederundervisning, får svar på frågor som de aldrig har ställt. Därmed får de studerande inte heller träning i att själva söka eller strukturera det vetande och de färdigheter som utvecklar deras beredskap att möta nytt i en föränderlig värld och som lägger grunden till det livslånga lärandet. Handledarens uppgift blir, fortsätter Egidius (1999:15), att träna de studerande att: "utifrån problemsituationer söka lösningar som kan hjälpa dem att fördjupa och vidga sin förtrogenhet med olika verklighets- och kunskapsområden."

PBL bygger alltså på en holistisk syn på lärande och utgångspunkten för arbetet är problem hämtade från en komplicerad verklighet. Detta medför, som Oliveira \& Berggren (1996:14) inskärper, att man löser problem "med hjälp av sin samlade omvärldskunskap, och där dras inga gränser mellan vardagskunskap och skolkunskap eller mellan kunskap från olika skolämnen."

Till de grundtankar som jag hittills har presenterat, kan man foga ytterligare en, nämligen att PBL förutsätter att arbetet organiseras och genomförs efter demokratiska principer. Egidius påpekar att studerandena "ska genom diskussionerna i gruppen [basgruppen] vänja sig vid att respektera andras åsikter, kunskaper och värderingar, så att de blir både kritiskt och självkritiskt inställda till de påståenden och uppfattningar som de möter i texter av olika slag." Dessutom, fortsätter Egidius, "ska de också vänja sig vid att de har kraft, förmåga och rätt att ha synpunkter på hur arbetet i gruppen ska gå till" (1999:14). Studentinflytande i PBL skiljer sig på många punkter från studentinflytande i traditionell utbildning. Alanko \& Isaksson (1999:64) diskuterar vad detta inflytande vanligen omfattar och konstaterar med hänvisning till forskning inom området att "om eleverna upplever sig ha inflytande gäller det ofta områden som inte direkt har med undervisningen att göra, utan mera med verkligheten runt omkring, t. ex. val av gardiner i klassrum." Alanko \& Isaksson (1999:64) delar in studentinflytande i formellt och informellt inflytande. Det formella omfattar val av kursrepresentanter, val till studentkåren, deltagande i institutionsstyrelser och arbetsgrupper o.s.v., medan det informella gäller inflytande över det egna lärandets former och innehåll. Detta inbegriper val av litteratur, undervisnings- och examinationsformer. Som Egidius uppmärksammar (1999:15), innebär detta "en ny lärarroll, som kan vara svår att vänja sig vid för dem som har hela sin läraridentitet byggd på att ge och förhöra läxor." Av detta ska man inte dra slutsatsen att läraren inte behövs, tvärtom bör läraren träna studerandena att: "utifrån problemsituationer söka lösningar som kan hjälpa dem att fördjupa och vidga sin förtrogenhet med olika verklighets- och kunskapsområden." (1999:15). Vad detta betyder mer konkret kommer jag att redovisa i nästa avsnitt som handlar om PBL som arbetsform.

\section{PBL som arbetsform}


Kortfattat kan man säga att renodlat PBL bedrivs i en s.k. basgrupp som består av 5-7 medlemmar samt handledare. Basgruppen utgör navet i studierna och träffas i början av utbildningen tillsammans med handledaren två gånger per vecka under cirka 1,5 timme. Enligt t.ex. Kjellman m.fl. (1993:49), bör det vara två till tre dagar mellan varje basgruppsträff, detta för att ge tillfälle till egna studier däremellan. I detta sammanhang bör man påpeka att schemalagda basgruppsträffar alltid är obligatoriska; det gäller närvaro och aktiv medverkan, eftersom basgruppsarbetet bl. a. syftar till att stimulera personlig utveckling och till att öka deltagarnas förmåga till att lyssna på andra.

Arbetet utgår från en beskrivning av en verklighetsanknuten situation som basgruppsmedlemmarna ska ta ställning till. Under detta arbete tas såväl vardagskunskap som skolkunskap i anspråk samtidigt som basgruppsmedlemmarna blir medvetna om vilka kunskaper de saknar och vilka frågor de måste formulera och själva söka svar på. Detta basgruppsarbete evalueras ständigt av medlemmarna, och det som de då utvärderar är gruppens samarbetsförmåga, de enskilda medlemmarnas och handledarens arbetsinsatser.

Basgruppsmedlemmarna blir på detta sätt medvetna om att lärande är en process som sker i flitigt samspel med andra människor.

Helt grundläggande för basgruppsarbetet är den redan nämnda sjustegsmetoden eller de sju stegen som på engelska kallas the seven jump. Sjustegsmetoden är ett slags arbetsschema eller dagordning som används under basgruppsarbetet. Med hjälp av detta schema, som handledarna lär basgruppsmedlemmarna använda under de första problemen som avhandlas i en kurs, kan de studerande styra sitt arbete konstruktivt och, som Egidius (1999:8) understryker, "komma bort från famlande, löst tyckande diskussion". Detta schema används tills metoden är internaliserad, d.v.s. tills studerandena har tillägnat sig ett strukturerat arbetssätt. Det schema som återges nedan är resultatet av en sammanvägning gjord på de mallar som Egidius (1999:8) och Kjellman m.fl. (1993:51) presenterar.

\section{De sju stegen}

Tillämpning av de sju stegen kräver att basgruppen samlats och att en skrivtavla finns i salen. Varje deltagare har ett exemplar av de sju stegen framför sig.

- Läs utgångspunkten (som kan vara en bild, en kort text, en vinjett o.s.v.) högt och begrunda denna en kort stund. Förklara begrepp, uttryck och termer. Notera fakta på skrivtavlan i en särskild kolumn.

- Definiera problemet och ev delproblem: Vilka fenomen eller företeelser vill gruppen belysa? Inför steg 3 ska gruppen ha valt det eller de problem som ska behandlas.

- Inventera gruppens uppfattningar och idéer om problemet. Börja bearbeta ett problem om det finns flera. Använd 5-10 minuters brainstorming per problem. Brainstorming: notera på tavlan alla förslag, idéer och associationer, som finns i gruppen, utan att kräva förklaringar eller kritisk granskning.

- Systematisera inventeringen. Granska de förslag som kommit fram. Peka på samband, kategorisera, värdera och sortera bort det som förefaller irrelevant.

- Formulera kunskapsmål. Avgränsa sådant, som ni inte förstår eller inte kan förklara. Formulera frågor och konkretisera kunskapsmål för de studier som ska ta vid och pågå fram till nästa sammankomst.

- Lär i olika former och med användning av olika källor. Varje gruppmedlem bör göra klart för sig vilken kunskap som han eller hon ska skaffa sig och på vilket sätt det ska ske. Man kan arbeta individuellt eller i grupp.

- Syntetisera den nyförvärvande kunskapen. Den nyförvärvade kunskapen ska sedan granskas i gruppen och diskuteras i förhållande till problemet. Kunskapen ska ge förutsättningar för fördjupad belysning av problemet och eventuellt besvara ställda frågor.

När studerandena har tillägnat sig de sju stegen och alltså lärt sig ett strukturerat arbetssätt, ställs efterhand ökade krav på deras förmåga att arbeta med problemlösning i förhållande till kommande yrkesutövning. 
I det schema som redovisas ovan antyds det i punkt sex att lärandet sker i olika former, och man kan ju fråga sig vad detta innebär. Även om PBL skiljer sig genomgripande från traditionell undervisning, så innebär inte detta att vissa av de lärandeformer som förekommer i just traditionell undervisning inte kan användas i PBL, även om de får en annan funktion. Exempel på detta är föreläsningen som mycket väl kan användas för att ge en introduktion till ett tema, ge en sammanfattning av ett ämnesområde, väcka intresse för ett ämnesområde eller belysa aktuell forskning inom ett område. Föreläsningarna är däremot få och tiden alltför dyrbar för att användas till sådant som är väl beskrivet i litteraturen. Även seminarier kan användas på olika sätt som komplement till basgruppsarbetet. Målsättningen med seminarierna är att väcka frågor och diskussion om något som basgrupperna arbetat med och att samtidigt ge möjlighet till övning i muntlig framställning. Seminarierna, vars sammansättning inte bör skifta under terminerna, kan t.ex. avsluta varje delkurs och bör bestå av 3-4 basgrupper. För en närmare beskrivning av kompletterande arbetsformer hänvisas till Kjellgren m.fl. (1993:56-61).

\section{Examination}

Examinationen är som alla vet utbildningssystemets eget sätt att mäta sina effekter och i normala fall godtas detta förfarande när man talar om utbildningens effektivitet. Det är också en utbredd uppfattning att examinationen först och främst är en bedömning av den studerande. Även om examinationen förstås har denna roll, vilket konstateras i Kjellgren m.fl. (1993:161), så är denna funktion vanligen överskattad, medan examinationens roll som återkoppling och styrinstrument vanligen är underskattad. Med hänsyn till examinationens avgörande betydelse för studenternas lärande - se t.ex.: Marton, Hounsell \& Entwistle (1998) och Ramsden (1992) samt högskoleverksrapporterna Uppfattningar om examination - en intervjustudie (1997:3 S) och Examination vid universitet och högskolor - ur studentens synvinkel (1997:10 S) - är det nära nog ofattbart att så obetydliga konsekvenser har dragits av denna vetskap när det gäller examinationen inom t.ex. humanistisk fakultet.

Det torde ha framgått av det som hittills sagts, att konventionella examinationsformer, som är inriktade på återgivande av faktakunskaper, inte är förenliga med PBL. Det kan nämligen inte, som Egidius påpekar, vara fråga om att läraren i rollen som domare och auktoritet fastställer hur mycket eller hur lite som studerandena har inhämtat av det som ålagts dem att lära in (1999:95-96). Det är snarare så att studerandena behöver lärarens hjälp att avgöra om de nått de insikter och färdigheter inom det område som utbildningen avser och som de i framtiden ska verka professionellt inom.

En vanlig examinationsform inom PBL är trestegsexamination eller triple jump. Denna form utvecklades på läkarutbildningen vid McMaster-universitet under 1970-talet och återges i Kjellgren m.fl. (1993:172-175):

\section{STEG 1: Problemdefinition (ca 30 minuter)}

Den studerande får ta del av en kort fallbeskrivning och kan för att bilda sig en uppfattning fråga examinatorn om ytterligare information. Den studerande får bara tillgång till de data som han uttryckligen frågar efter. När studeranden inhämtat tillräcklig information ska han eller hon formulera en preliminär frågeställning samt identifiera relevanta problem. Här synliggörs studerandens kunskaper och förståelse av bakomliggande mekanismer och förklaringar till problemet. Det blir också tydligt vad han eller hon måste inhämta ytterligare kunskaper om för att kunna lösa problemet.

\section{STEG 2: Självständiga studier (ca 2-24 timmar)}

Studeranden söker information för att besvara de frågor som formulerats. Det är tillåtet att använda vilka källor som helst: bibliotek, kurslitteratur, resurspersoner, studiebesök o.s.v. Studeranden uppmanas att inför steg 3 föra anteckningar över sin strategi och över vilka källor som utnyttjas under de självständiga studierna.

\section{STEG 3: Problemsyntes (ca 30 minuter)}

Studeranden återkommer till examinatorn och har nu möjlighet att revidera sin preliminära 
problemformulering efter att ha inhämtat ny kunskap. Studeranden redogör för bakomliggande mekanismer till problemet, föreslår målsättning och handlingsalternativ samt diskuterar de kriterier för utvärdering av sin behandling [detta är en beskrivning avsedd för vårdutbildningar]. Som underlag för bedömning av studeranden av en skattningsskala vars ändpunkter består av beskrivande omdömen om studerandens prestation i olika avseenden.

Det är emellertid viktigt att understryka att andra examinationsformer är möjliga och mer information ges i Oliveira \& Berggren (1996:100-114) och Egidius (1999:95-96) samt i Högskoleverkets rapport Råd och idéer för examinationen inom högskolan (1997:14 S).

\section{Vilka erfarenheter finns av PBL och språkundervisning?}

Inledningsvis kan man erinra om att de erfarenheter som gjorts - i alla fall som dokumenterats och publicerats - har ägt rum i gymnasieskolan. Den läsare som är förtrogen med Oliveria \& Berggren (1996) kommer att märka hur mycket jag förlitar mig på deras i mitt tycke utmärkta PBL i språkundervisningen. Om problembaserat lärande i teori och praktik.[8] Deras bok är resultatet av ett PBL-projekt inom invandrarundervisningen och består av två delar: en handledningsbok och ett kopieringsunderlag; jag har endast haft tillgång till handledningsboken.

Vilka lärdomar är det då som dragits på gymnasienivå och på vilket sätt kan dessa lärdomar vara till hjälp på högskolenivå? Det vore naturligtvis utmärkt om man kunde på ett enkelt sätt redogöra för de erfarenheter som gjorts och utifrån dessa förutse tämligen detaljerat hur PBLarbetet skulle föras in och sedan gestaltas i den akademiska språkundervisningen. Detta låter sig emellertid inte göras av flera skäl, kanske främst beroende på att PBL inte endast kan beskrivas som en färdig metod utan även som en genomtänkt grundsyn på kunskap och lärande. Vad detta innebär har redan berörts, men det står klart att vissa preciseringar kan göras på grundval av den erfarenhet som vunnits på gymnasienivå. Oliveira \& Berggren (1996:19-24) understryker t.ex. att det krävs förändringsbenägenhet hos både skola och lärare. Lärarrollen måste förändras, eftersom lärarens uppgift inte längre blir att ansvara för att eleverna lämnar skolan med en viss mängd färdig kunskap, utan i stället att borga för att eleverna lämnar skolan med den kompetens de behöver för att kunna söka, bearbeta och tillämpa kunskap i ett socialt sammanhang. Lärarens mål blir inte längre att endast förmedla ämneskunskaper, vilket kan vara svårt att acceptera i alla läger.

\section{PBL i språkundervisningen på grundläggande nivåer}

Oliveira \& Berggren har i sitt projekt använt PBL som ett medel för att integrera språkundervisning och samhällsorientering dels för vuxna invandrare, dels för invandrarungdomar. Det är naturligtvis inte exakt samma sak som att använda PBL i undervisningen i franska för svenska studenter, men det finns så många gemensamma utgångspunkter att det mycket väl kan vara överförbart till undervisningen i främmande språk. För att konkretisera vad det innebär att inta ett problembaserat förhållningssätt i språkundervisningen är det lämpligt att jämföra denna med vad ett traditionellt inbegriper. Jag har här valt att så gott som verbatim följa den argumentation som Oliveira \& Berggren för, och detta utan att egentligen ha några invändningar, dels eftersom min egen erfarenhet av språkundervisning konfirmerar deras framställning av den konventionella, dels eftersom jag starkt sympatiserar med och inspireras av deras erfarenhet av den problembaserade undervisningen.

I traditionell språkundervisning betraktas lärandet som en linjär process. Undervisningen är oftast läromedelsstyrd och framskrider därmed enligt en viss förutbestämd progression, ofta från det konkreta till det abstrakta, från ett situationsbundet till ett icke-situationsbundet språk eller från det som traditionellt betraktas som ett lätt språk till ett svårt språk. De olika språkfärdigheterna tränas systematiskt men ofta isolerat från varandra. Förväntningarna på elevens förmåga att själv sätta samman delmomenten till en fungerande helhet är stor.

\begin{tabular}{|l|l|l|l|l|l|l|l|l|}
\hline & Kommunikativ
\end{tabular}


\begin{tabular}{l}
$\begin{array}{l}\text { Icke kommunikativ } \\
\begin{array}{l}\text { Elev kan inte använda } \\
\text { språket }\end{array}\end{array} \rightarrow \mid$ glosor $|+|$ uttal $|+| \begin{array}{l}\text { läromedels- } \\
\text { text }\end{array}|+|$ grammatik $|+|$ annat $|=| \begin{array}{l}\text { Elev kan } \\
\text { använda } \\
\text { språket }\end{array}$ \\
\hline
\end{tabular}

Bild 1 Språkinlärning betraktad som en linjär process. Här tränas de olika språkfärdigheterna systematiskt men delvis isolerade från varandra (illustration av Ann Sofi Marminge och text från Oliveira \& Berggren 1996).

I utfallet av dessa förväntningar, kan man hänvisa till L. O. Dahlgrens artikel i Kjellgren m.fl. som konstaterar: "I ett tämligen stort antal undersökningar har det framgått att en stor del av de studerande, ibland en majoritet, inte uppfattat utbildningens mest centrala begrepp med den innebörd som avsetts" (1993:18). Att presentera en färdig struktur medför alltså inte automatiskt förståelse för denna struktur.

Men språkundervisningen kan också utgå från ett synsätt som inte är läromedelsstyrt och som inte bedrivs enligt en i förväg fastställd progression. I stället för att utgå från ett läromedel utgår man från verkligheten. Strävan är att skapa ett äkta uttrycksbehov hos eleverna och att sedan låta dessa behov styra lärandet. Därmed kan förstås inte lärandet ske linjärt från det konkreta till det abstrakta, från ett situationsbundet till ett icke-situationsbundet språk eller från ett lätt språk till ett svårt språk. Lärandet måste i stället ske på flera parallella nivåer samtidigt, där elevernas intresse och språkliga behov växelvis styr in i ett konkret respektive abstrakt eller ett lätt respektive svårt ordförråd.

Förutsättningen för att PBL ska kunna tillämpas i språkundervisningen är alltså att läraren ansluter sig till en syn på språklärande som liknar den som framgår av nedanstående bild.

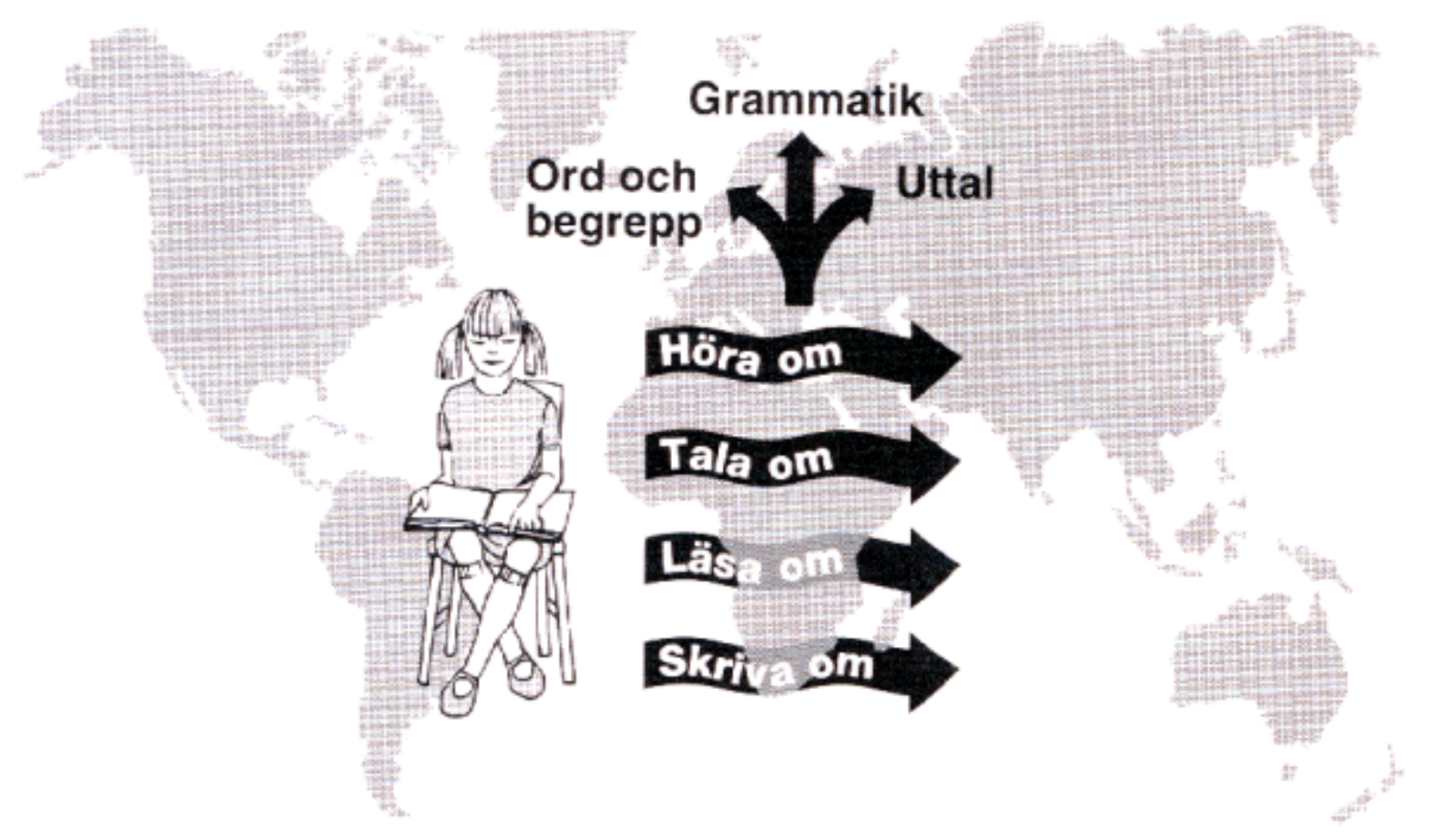

Bild 2 Språkinlärning betraktad som en integrerad process. Här är omvärldskunskap både mål och medel, och de olika språkfärdigheterna måste utvecklas i ett helhetssammanhang (illustration av Ann Sofi Marminge och text från Oliveira \& Berggren 1996).

Om man arbetar utifrån denna syn, menar Oliveira \& Berggren att PBL kan introduceras i undervisningen ganska tidigt. Om man däremot arbetar efter en traditionell syn på språklärande (bild 2, s. 14) är man förmodligen av den åsikten att eleven först måste lära sig de ord och de uttryck samt den grammatik som kommer att behövas i ett PBL-arbete, innan ett fall introduceras. Denna lärare uppfattar således PBL-arbetet som ett slags tillämningsövning, och det kommer troligen att ta lång tid innan eleverna har de kunskaper som hon anser nödvändiga för att hon ska släppa in PBL i undervisningen. 
Eftersom PBL bygger på uppfattningen att man lär sig i interaktion med andra, och grunden för denna interaktion är språket, är det också, åtminstone att döma av den erfarenhet som Oliveira \& Berggren redovisar, synnerligen lämpat för språkundervisning. I PBL blir språket - till skillnad från traditionella tal- och skrivövningar - ett medel som man utnyttjar för att lösa ett verkligt problem utan att fokusera på vad man tidigare gått igenom i undervisningen. I PBL arbetar man alltså med problemlösning, och lärande äger rum under själva arbetsprocessen. Eleverna lär under diskussioner i problemformulerandet, i informationssökandet, under bearbetningen och i redovisningarna. Arbetsprocessen erbjuder samordnad träning och utveckling, och dessa färdigheter utvecklas inte isolerande från varandra utan i ett sammanhang som en helhet, vilket kan illustreras på följande sätt:

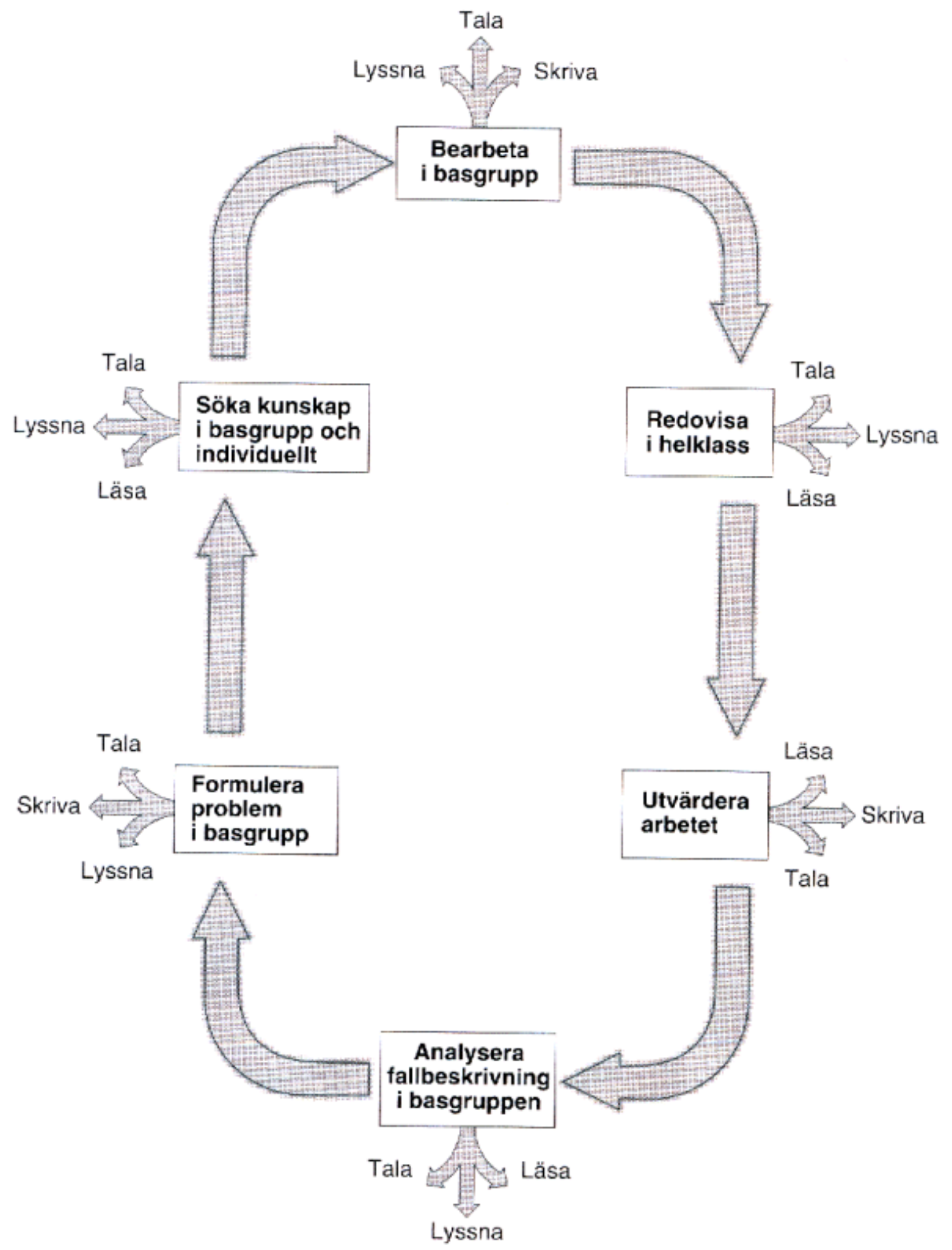

Bild 3 Genom PBL-arbetet utvecklas de olika språkfärdigheterna inte isolerade från varandra utan i ett 
Men är det då möjligt att arbeta med PBL i språkundervisningen? Ja, när det gäller gymnasienivån skriver Oliveira \& Berggren (1996:20): "Vi vet naturligtvis av egen erfarenhet att det är möjligt, men vi tror att det i grund och botten är den enskilda läraren syn på språkinlärning som avgör svaret på den frågan." Är PBL också genomförbart i språkutbildningen på akademisk nivå? Svaret måste bli jakande, menar jag. I nästa avsnitt, som är artikelns sista, ska något kort sägas om hur pass effektivt PBL är i förhållande till traditionell undervisning.

\section{Är PBL effektivare än traditionell undervisning?}

Det torde ha framgått av framställningen hittills att PBL inte endast är en metod utan också ett förändrat sätt att se på lärande. Vad detta innebär och vad som kännetecknar denna kunskapssyn har presenterats tidigare. Det kan då finnas anledning att fråga sig vilka problem som man anser sig lösa på ett bättre sätt med PBL än med traditionell undervisning. Svaret på denna fråga har antytts i de avsnittet om PBL och språkutbildning, där ett viktigt argument var att arbetsprocessen i basgruppen utgör ett utmärkt tillfälle till ökade färdigheter i att använda målspråket. Men det finns fler argument och fyra av dessa redovisas i Kjellgren m.fl. (1993:2327).

Det första argumentet är det meningsfulla lärandets krav på begripliga helheter, d.v.s. behovet av pedagogiska gestalter. Detta innebär att studerandena måste kunna känna igen sig i den yrkesmässiga verklighet som utbildning förbereder dem för. Det ska finnas en samlande frågeställning i bakgrunden till vilken man slutligen alltid ska återvända. Detta första argument är tämligen självklart inom en rad utbildningar som är direkt yrkesförberedande som t.ex. vårdutbildningar, men man kan fråga sig om detta gäller också inom en disciplin där den framtida yrkesverksamheten inte är lika tydlig under studietiden? För språkstudier kan den pedagogiska gestalten vara en person som har goda kunskaper i hur ett land fungerar dels i detalj (t.ex. vilka regler som gäller för utbytesstudenters rätt till bostadsbidrag), dels i allmänhet (t.ex. vilka normer och värderingar som genomsyrar lagstiftning, kultur- och samhällsliv). Att denna person kan redogöra för sina kunskaper också på målspråket är en självklarhet. Märk väl att en sådan helhetssyn inte utesluter fördjupning i detaljkunskaper om t.ex. målspråkets verbsystem. Tvärtom förutsätts en person med kunskaper om t.ex. landets historia och geografi också känna till vilka verb som är oregelbundna och hur de böjs.

Det andra argumentet gäller kunskapens användbarhet utanför utbildningssituationen. I samband med nyanställning brukar arbetsgivaren räkna med en inkörningsperiod innan personen i fråga är fullt kapabel att arbeta självständigt. Detta förhållande kan i viss mån bero på att utbildningskunskaper är artskilda från arbetslivets kunskapsbehov. Eftersom arbete ofta innebär att lokalisera, formulera och lösa problem samt att eventuellt dokumentera lösningarna, kan man fråga sig varför dessa färdigheter i så ringa grad förekommer i traditionella övningar, där det snarare är fråga om att lösa och dokumentera förelagda problem på ett stereotypiskt sätt. PBL medför här en ökad autenticitet under utbildningstiden i förhållande till arbetets krav. Med tanke på i vilken ringa omfattning som t.ex. språkstuderande övar sig på att såväl skriftligt som muntligt behandla problem på såväl modersmålet som målspråket är det naturligt att också denna studentkategori behöver en viss inkörningsperiod vid första anställningen. Men det finns anledning att ifrågasätta detta, eftersom språkstudenter - om några - förväntas vara väl tränade i dessa moment.

Det tredje argumentet gäller det traditionella sättet att examinera kunskaper och färdigheter. Traditionell examination är till sin natur asocial i bemärkelsen att den utgör en privat kraftmätning mellan studeranden och uppgiften. Förelagd en väl definierad uppgift ska studeranden av egen kraft lösa denna med egna kunskaper. Lösningen bedöms därefter av läraren som alltså är den ende som får ta del av studerandens ansträngningar. Eftersom redogörelse av kunskap och färdigheter utgör ett verkningsfullt inlärningstillfälle framstår det som ett "omotiverat slöseri att göra denna till en privat angelägenhet" (1993:25). För detta 
arguments relevans för språkundervisning, hänvisar jag till föregående avsnitt.

Ett fjärde argument är att utbildningar inte bara resulterar i kunskaper och färdigheter hos de studerande utan också ger upphov till mer grundläggande effekter. Bland de effekter som förs fram räknas förhållningssätt till kunskap och lärande, förmåga att självständigt söka, ordna, syntetisera och dokumentera kunskap samt inte minst utvecklandet av ett vetenskapligt förhållningssätt, d.v.s. benägenheten att förhålla sig kritisk till vad som påstås om vår omvärld och vissheten om att några eviga sanningar knappast existerar. PBL accentuerar ett förhållningssätt som medger träning i dessa moment.

Om dessa angivna argument gör det möjligt att sluta sig till att PBL är effektivare än traditionell undervisning, kan man givetvis ha olika uppfattningar om. Det som står klart är att de verkar tillräckligt starka för att prövas inom ramen för den akademiska språkutbildningen.

\title{
Några reflexioner
}

Denna artikel innehåller tre avsnitt vilka tillsammans representerar några av de frågor - eller problem om man så vill - som jag har ställt mig under loppet av den kurs i

universitetspedagogik för lärare som UPC i Växjö anordnade under läsåret 1999/2000. Det är ingen överdrift att säga att denna kurs på ett genomgripande sätt har förändrat min syn på lärande. Kursen har givit mig insikter som otvivelaktigt är väsentliga också i ett extramuralt perspektiv. Men det som kanske förvånat mig mest är emellertid de vattentäta skott som finns mellan pedagogisk forskning om lärande och praktisk språkundervisning vid våra universitet. Den förnyelse som antyds i titeln är, menar jag, inte särskilt konkret och det finns all anledning att fråga sig varför det är så och vad som kan göras åt denna diskrepans.

\section{Mathias Pålsson}

\section{Litteraturförteckning (tematisk)}

\author{
Allmänt \\ Brodow, B., Nilsson, N.-E. \& Ullström, S.-O., 2000, Retoriken kring grammatiken. Didaktiska \\ perspektiv på skolgrammatik, Lund: Studentlitteratur. \\ Enkvist, I., 2000, Feltänkt: kritisk granskning av idébakgrunden till svensk utbildningspolitik, \\ Stockholm: SNS förlag.
}

\section{Bakgrund}

Kursplaner och kursbeskrivningar för 1-20-poängsnivåerna i Växjö och Lund.

Frihet, ansvar, kompetens. Grundutbildningens villkor i högskolan (SOU 1992:1).

Nya villkor för lärandet i den högre utbildningen (SOU: 2001:1).

Dysthe, O., 1996, Ulike perspektiv på læring og læingsforskning, Oslo: Cappelen.

Marton, F., Hounsell, D. \& Entwistle, N., 1998, Hur vi lär, Stockholm: Rabén Prisma.

Ramsden, P., 1992, Learning to teach in higher education, London: Routledge.

\section{Examination}

Uppfattningar om examination - en intervjustudie (1997:3 S).

Examination vid universitet och högskolor - ur studentens synvinkel (1997:10 S).

Extern medverkan i examinationen. Nordiska och brittiska traditioner. Svenska försök (1997:11

S).

En auktoritär prövning eller en prövning av auktoritet? Examination vid universitet och högskolor (1997:12 S).

Råd och idéer för examinationen inom högskolan (1997:14 S).

\section{PBL}

Alanko, L. \& Isaksson, L., 1999, Problembaserat lärande i praktiken - för gymnasieskolan, Stockholm: Liber.

Barrows, H.B. \& Tamblyn, R., 1980, Problem-based learning. An Approach to Medical 
Education, New York: Springer Publishing Company Inc.

Egidius, H., 1999, Problembaserat lärande - en introduktion för lärare och lärande, Lund:

Studentlitteratur.

Kjellgren, K m.fl.(red.) 1993, Problembaserad inlärning - erfarenheter från Hälsouniversitet, Lund: Studentlitteratur.

\section{PBL i språkundervisningen}

Oliveira, G. \& Berggren, M., 1996, PBL i språkundervisningen, Stockholm: Natur och Kultur.

[1] Oliviera, G. \& M. Berggren (1996) och A. Alanko \& L. Isaksson (1999).

[2] Se Studentbarometern, Arbetsrapport vid institutionen för samhällsvetenskap, Växjö universitet (2000).

[3] Utbildnings- och forskningsminister Thomas Östros slår i Universitetsläraren 8/2000 fast att studenternas lärande ska stå i centrum för arbetet med att förnya undervisningsformerna och att det är viktigt för en fortsatt hög kvalitet i högskolan att detta arbete intensifieras. Att dessa frågor prioriteras framgår även i det betänkande som Anders Fransson nyligen presenterade. I detta betänkande, Nya villkor för lärandet i den högre utbildningen (SOU 2001:13), ägnas tre kapitel åt pedagogiskt utveckling : kap 8 understryker vikten av stöd för pedagogisk förnyelse, kap 10 föreslår kompetensutveckling för högskolans lärare och kap 11 behandlar pedagogisk skicklighet som meriteringsgrund - karriärplanering - incitament för god undervisning. [4] Se t ex PM till ledning vid ansökan om anställning som/befordran till professor och universitetslektor vid SLU (2000).

[5] Utvecklingsplan för Växjö universitet 2000-2004 (2000).

[6] Märk väl att min erfarenhet av undervisning, efter snart tio års universitetsstudier, är ganska stor.

[7] Kjellgren m.fl. (1993) förmedlar erfarenheter av just PBL inom Hälsouniversitetets utbildningar.

[8] Det finns emellertid invändningar mot en problembaserad undervisning på lägre nivåer. T.ex. ställer sig I. Enkvist, som i flera intressanta skrifter har undersökt olika aspekter av språkundervisning och lärande, starkt kritiskt mot att tillämpa PBL på gymnasiet, eftersom elever i denna ålder inte kan förväntas ta ansvar för sitt lärande på ett sådant sätt som är tillrådligt. 